\title{
Confluence. Introduction
}

Claire Omhovère

\section{OpenEdition}

1 Journals

Electronic version

URL: http://journals.openedition.org/ces/279

DOI: $10.4000 /$ ces. 279

ISSN: 2534-6695

\section{Publisher}

SEPC (Société d'études des pays du Commonwealth)

\section{Printed version}

Date of publication: 1 April 2018

Number of pages: 5-7

ISSN: 2270-0633

\section{Electronic reference}

Claire Omhovère, "Confluence. Introduction", Commonwealth Essays and Studies [Online], 40.2 | 2018

Online since 05 November 2019, connection on 06 April 2021. URL: http://journals.openedition.org/ ces/279; DOI: https://doi.org/10.4000/ces.279

\section{(c) (i) () $\Theta$}

Commonwealth Essays and Studies is licensed under a Licence Creative Commons Attribution - Pas d'Utilisation Commerciale - Pas de Modification 4.0 International. 


\section{Confluence \\ Introduction}

It is a tradition for the organizers of the annual conference of the Sociéte des Anglicistes de l'Enseignement Supérieur (SAES) to choose a topic that will be found doubly relevant, first as conducive to exchanges across the disciplines constitutive of English studies, and second as emblematic of the region where the event is hosted. The 2016 SAES conference took place in Lyon, the city where the mighty Rhône and sedate Saône rivers flow together, at the very tip of the peninsula or "Presqu'île" nestled between the two hills of Fourvière and La Croix Rousse. "Confluence" was therefore the theme proposed to the delegates who met there between June 2 and June 5, 2016. The site's geography played an essential role in the development of the Roman military camp that became the capital of the Gauls as Lugdunum flourished between the Renaissance and the industrial revolution, and is now the most important educational centre in France after Paris, at least if we are to believe the Encyclopaedia Britannica. It also happens that Lyon is my hometown, the city where I grew up and went to university to study English. It is a rather apt and, to me at least, moving coincidence that my 2011-2017 mandate as general editor of Commonwealth Essays and Studies and president of the Société d'Etude des Pays du Commonwealth (SEPC) should come to an end with the publication of this joint issue for which I have edited six essays. Four of them were presented during the 2016 Confluence conference, but all of them engage with its federating topic on several, complementary levels as shall now be seen.

There is something profoundly irenical in the idea of confluence, the dynamics that bring different purposes and (fluvial) temperaments to converge, former divergences diluting into a common course, giving birth to new currents and fresh realities. Viewed through this conciliatory prism, the geographical trope may not be the most adequate to apprehend the synergies that have shaped postcolonial literatures, fraught as they have always been with the antagonisms imperial rule encouraged or sometimes introduced among the populations and territories it sought to control. Another factor of disturbance and current transformation lies in the effects of globalization and the emergence of diasporic, transnational and increasingly transcultural literatures in which the postcolonial is just one possible affiliation among others. Postcolonialism is a shifting and increasingly contested field. It is then perhaps not fortuitous that the terms postcolonial scholars have diverted from their literal usage to serve critical purposes should tolerate a high degree of heterogeneity in the very forms of contact and subsequent alterations they make intelligible. Mimicry, hybridity and creolization are prominent examples of this, while reconciliation, as in the various Truth and Reconciliation Commissions that have been taking place in Britain's former colonies in recent decades, remains a collective horizon difficult to reach in spite of the efforts displayed on all sides. A case in point is the public controversy sparked in 2017 by Canada 150, the commemoration of the $150^{\text {th }}$ anniversary of the Canadian Confederation that many indigenous leaders 
refused to celebrate on account of the "one hundred and fifty years of ongoing colonialism" which the year 1867 inaugurated for Canada's First Nations. ${ }^{1}$

Proposing to observe the operations of confluence in postcolonial literatures certainly involves paying attention to the fluidity and permeability the geographical analogy helps identify in terms of thematisation, representation, and critical conceptualization. But confluence, it must be pointed out, is also a zone of turbulence where currents coming from different sources rush to impose a direction to the flow. Here, I believe, lies the productive tension that informs the essays to follow, insofar as the latter do not give pride of place to conciliation over the eddies of resilience or resistance, but carefully work out the modalities of their uneasy coexistence in literatures that keep challenging critical reception with their inventiveness.

Marie Herbillon's chronotopic approach emphasizes the confluence of time and space in the essay she devotes to Murray Bail's Notebooks. Once she has shown how the relationships between self and place undergo a redefinition in Murray's "geotobiography," Herbillon works from the neologism she borrowed from Frédéric Regard to elaborate on the effects of "extrospection" in a hybrid genre that allows "a plural and dynamic approach to selfhood, whereby a contemporary sense of Australianness is evolved through the dispersion of unified, static and potentially hegemonic identities."

Adrian Grafe's essay follows a circuitous course in its approach to J.M. Coetzee's Waiting for the Barbarians. If confluence first seems to prevail in the entwining of the Magistrate's and the Barbarians' fates, Grafe however chooses to concentrate on the conflict the Magistrate's conscience has internalized between his aspirations for justice and the authority he embodies as a representative of the law. The essay finally ponders over the value of waiting, the receptiveness through which the Magistrate resists the role the regime forced upon him, and reclaims an ethical sense of self grounded in a shared humanity.

In her own contribution, Alice Michel engages in a reappraisal of Ada Cambridge's A Woman's Friendship. First published in Australia in the 1880s, this serial novel has frequently been dismissed as "too romantic, too domestic, or even too conservative." The essay, however, identifies in its ambivalence the seeds of a radicalism that has long passed unnoticed. A pioneer concern for social issues converges in Cambridge's writing with a questioning of gender norms and a sly feminist positioning that allows the author to steer around the rules of Victorian propriety while avoiding a direct confrontation with the conservative expectations of a colonial audience.

Sara Arami chose to discuss The Girl in the Tangerine Scarf, a coming-of-age novel by Mahja Kahf, a Syrian-American writer. The essay focuses on the dilemma faced by female Muslim writers who grew up in the West and constantly run the risk of re-orientalizing their culture of origin, the object of great emotional investment on their part. Arami pays close attention to the novel's turning point where the heroine realizes that her ideal of an authentic Islam immune to the global reach of Westernization does not exist, except perhaps in her imagination. The ending of the novel, a happy confluence

1. In a feature article for The Guardian, Ashifa Kassam presents a documented overview of the controversy that includes a link to the travelling exhibition Shame and Prejudice: A Story of Resilience by Kent Monkman, a prominent artist of Cree origin. The exhibition is a fine example of the counter-celebration organised by the vanguard of Canada's Indigenous artists, and a great antidote against the complacency that occasionally surfaces with retrospective views on Canada's history of interracial relations. 
if there is one, nevertheless requires a careful assemblage of objects, rituals, and texts for the novel's heroine to succeed in bringing her culture home to the US.

In "The Flowing Together of Politics and Poetics," Cédric Courtois proposes an indepth analysis of three novels by Nigerian writer Helon Habila. Courtois first replaces Habila's oeuvre in the historical context of the building of the Nigerian project, a political process in which literature has been put to task to foster national reconciliation after one civil war and many years of brutal dictatorship. He then moves on to analyse how politics and poetics strikingly converge in Habila's critique of Nigeria's current petroculture, before enlarging on his experimentation with the hybrid genre of "faction."

Finally, hybridity is also central to the essay Sandrine Soukai devotes to Amitav Ghosh's The Shadow Lines and Kamila Shamsie's Burnt Shadows. Her analysis throws light upon the transformations the Anglo-Indian novel underwent following the 1947 Partition, in reaction to the rise of competing nationalist discourses in India and Pakistan. Although Ghosh and Shamsie now stand on separate sides of the boundary dividing the two countries, their novels reinstate a sense of commonality, beyond the shared trauma of Partition, by relying upon the cross-cultural memory deposited in the various Indian literatures they draw upon, "thus creating hybrid narratives whose texture reflects their plural definitions of concepts such as the nation, identity and culture."

\author{
Claire OMHOvÈRE \\ Paul-Valéry University - Montpellier / EMMA
}

\title{
Works Cited
}

Kassam, Ashifa. "Canada celebrates 150 but indigenous groups say history is being 'skated over'." The Guardian 27 June 2017. https://www.theguardian.com/world/2017/ jun/27/canada-150thanniversary-celebration-indigenous-groups. Consulted 15 March 2018. 